\title{
ANALISIS KESTABILAN TEROWONGAN MENGGUNAKAN METODE CONVERGEN-CONFINEMENT (CCM) BERDASARKAN DATA HASIL PEMANTAUAN
}

\author{
L.M. Hilman Kurnia \\ Program Studi Teknik Pertambangan, Universitas Dayanu Ikhsanuddin \\ email: laodehilman@gmail.com
}

\begin{abstract}
Abstrak
Abstrak : Kestabilan terowongan menjadi hal yang krusial dalam mendesain terowongan. Stabilitas terowongan dipengaruhi oleh kondisi batuan di sekitar terowongan. Karena kompleksitas dan ketidakpastian yang ada di alam, observasi dan interpretasi yang cermat tentang apa yang dapat diukur di lapangan menjadi prasyarat bagi para insinyur geoteknik untuk melakukan pekerjaan konstruksi yang aman. Salah satu metode yang digunakan yaitu Metode Convergen-Confinement (CCM), yang berupa metode observasi dengan pendekatan standar untuk analisis awal dari perpindahan yang terjadi di batas galian terowongan dengan tekanan penyangga yang dibutuhkan untuk mencegah terjadinya perpindahan tersebut. Pengukuran perpindahan dengan menggunakan alat total station untuk memudahkan kegiatan pemantauan pada dinding dan atap terowongan. Perpindahan yang terjadi pada batuan Breksi Vulkanik dari hasil pemantauan di lapangan $1,9 \mathrm{~mm}$ untuk dinding kiri-kanan dan atap sedangkan untuk hasil perhitungan perpindahan yang terjadi pada pada massa batuan setelah disangga adalah $1,2 \mathrm{~mm}$ dan $1,45 \mathrm{~mm}$ (titik equilibrium). Perpindahan yang terjadi pada batuan Claystone dari hasil pemantauan di lapangan 5,5 mm untuk dinding kiri-kanan dan atap sedangkan untuk hasil perhitungan perpindahan yang terjadi pada pada massa batuan setelah disangga adalah $3,5 \mathrm{~mm}$ dan $4 \mathrm{~mm}$ (titik equilibrium).
\end{abstract}

Kata kunci : Metode convergen-confinement, perpindahan, metode analitik, metode numerik, penyangga

\begin{abstract}
Tunnel stability is crucial in tunnel design. Tunnel stability is influenced by rock conditions around the tunnel. Due to the complexity and uncertainty inherent in nature, careful observation and interpretation of what can be measured in the field is a prerequisite for geotechnical engineers to carry out safe construction work. One of the methods used is the Convergen-Confinement (CCM) method, which is an observation method with a standard approach for initial analysis of displacements occurring at the tunnel excavation boundary with the required buffer pressure to prevent such displacements.. Measuring displacement using a total station tool to facilitate monitoring of the walls and roof of the tunnel. The displacement that occurs in Volcanic Breccia from the results of monitoring in the field is $1.9 \mathrm{~mm}$ for the left and right walls and roof while the results of the displacement calculation that occur at the rock mass after support are $1.2 \mathrm{~mm}$ and $1.45 \mathrm{~mm}$ (equilibrium). The displacement that occurs in Claystone rocks from the results of monitoring in the field is $5.5 \mathrm{~mm}$ for the left-right and roof wall while the results of the displacement calculation that occur in the rock mass after support are $3.5 \mathrm{~mm}$ and $4 \mathrm{~mm}$ (equilibrium).
\end{abstract}

Keywords: Convergent-Confinement Method, displacement, analytic method, numerical method, support

\section{PENDAHULUAN}

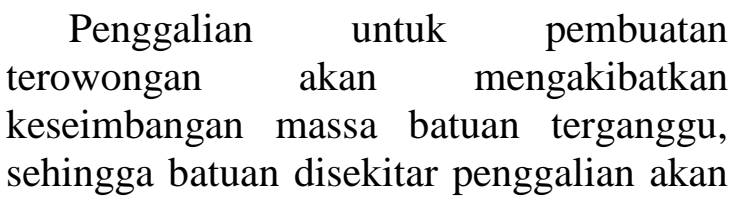

mengalami keruntuhan apabila batuan tersebut tidak mampu menyangga bebannya sendiri. Dalam mendesain terowongan, kestabilan terowongan menjadi hal yang krusial. Kestabilan 
terowongan dipengaruhi oleh kondisi batuan di sekitar terowongan, kedalaman terowongan yang akan dibangun, lebar bukaan dan kemajuan terowongan yang direncanakan serta jenis penyanggaan yang digunakan.

Tantangan penting lainnya dalam mendesain terowongan adalah bagaimana terowongan tersebut tetap stabil selama masa pemakaiannya. Pada saat terowongan digali, tegangan awal insitu $P o$ akan didistribusikan dan mencari kondisi keseimbangannya kembali. Perubahan tegangan terjadi akibat perpindahan massa batuan bergerak kearah terowongan. Besarnya perpindahan konvergen tergantung pada karakteristik massa batuan dan geometri terowongan. Pemantauan adalah pengamatan terhadap struktur rekayasa baik secara visual maupun dengan bantuan peralatan. Dalam konteks geomekanika, pemantauan umumnya dilakukan untuk beberapa tujuan utama (Brady \& Brown dalam Rai dkk, 2012).

Metode Convergen-Confinement (CCM) untuk terowongan merupakan pendekatan standar untuk analisis awal dari perpindahan yang terjadi di batas galian terowongan dengan tekanan penyangga yang dibutuhkan untuk mencegah terjadinya suatu perpindahan tersebut. Penggunaan metode ini dapat dilakukan dengan menggunakan solusi analitik (bentuk tertutup) atau dengan model numerik.

Penggunaan menggunakan metode elemen hingga tiga dimensi (FEM) atau numerik untuk menganalisis perpidahan massa batuan disekitar terowongan yang berbentuk lingkaran melalui massa batuan yang lemah, sehingga menunjukkan pola perpidahan dalam massa batuan (Hoek, 1998).

\section{METODE PENELITIAN}

Metode convergen-confinement digunakan untuk menganalisis kestabilan terowongan dengan membuat kurva interaksi batuan-penyangga untuk mendapatkan besar dan arah perpindahan melalui perhitungan solusi numerik dan analitik. Metode ini menggunakan analisis balik dari hasil pemantauan di lapangan dengan hasil perhitungan dari kurva interaksi batuan-penyangga, karena perpindahan yang diukur di lapangan adalah perpindahan yang "sebenarnya" dari massa batuan di dalam terowongan.

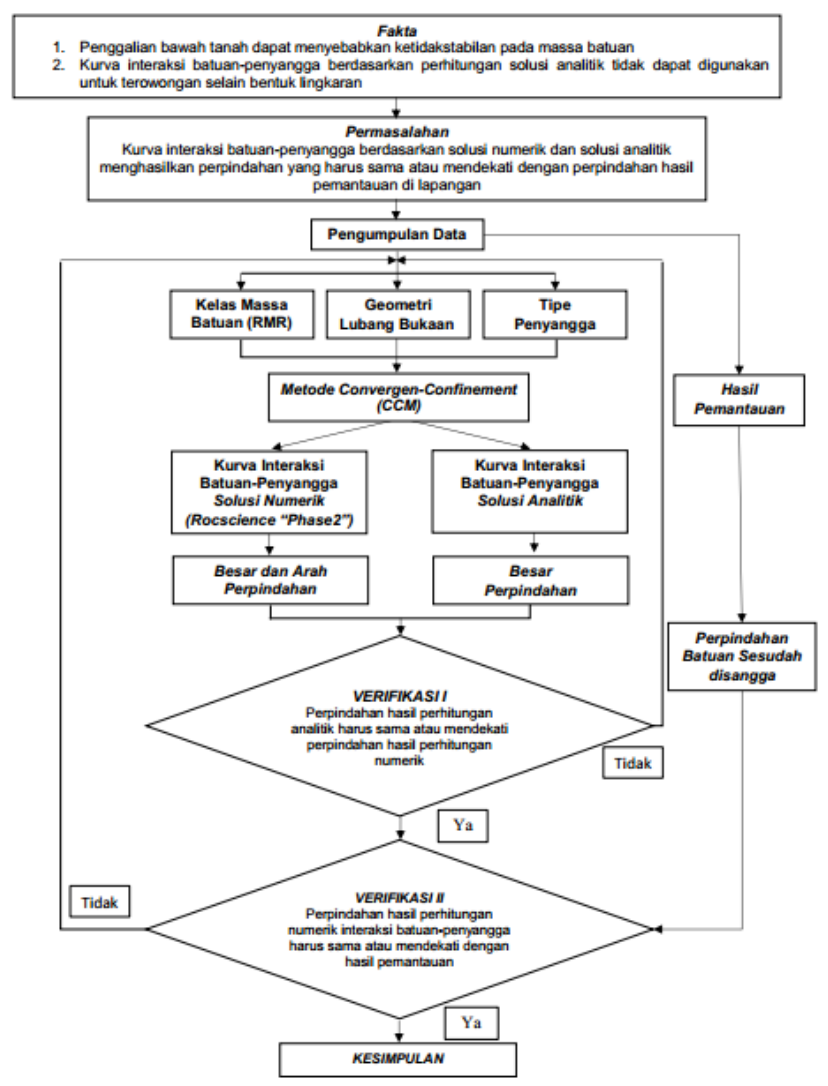

Gambar 1. Diagram Alir Metodologi Penelitian

\section{Pengambilan Data}

Pengambilan data untuk pemodelan dan hasil pemantauan dilakukan di dua titik STA (Stasiun) yang berbeda yaitu STA 359+185 dan STA 359+549. Pada STA 359+185 terdapat batuan Breksi Vulkanik dan STA 359+549 terdapat batuan Claystone. 
Di setiap titik pengamatan yang dilakukan, tegangan in-situ $P o$ (in-situ stress) berbeda-beda. Besarnya insitu stress yang terjadi pada lubang bukaan dapat ditentukan dengan dua parameter yaitu, koordinat vertikal (z) dalam hal ini lokasi terowongan bila diukur dari permukaan tanah dan yang kedua adalah densitas untuk tiap jenis batuan.

1. Kurva Interaksi Batuan Penyangga Berdasarkan Solusi Analitik

Tujuan utama merancang penyangga pada lubang bukaan adalah untuk membantu massa batuan menyangga dirinya sendiri. Sedangkan untuk memberikan estimasi seberapa besar beban yang akan ditopang oleh penyangga batuan di belakang muka terowongan dibuatlah suatu kurva interaksi batuan-penyangga yang mana tegangan in-situ horizontal dan vertikal dianggap sama dengan $P_{o}$.

a. Breksi Vulkanik

Data yang sudah ada kemudian dilakukan perhitungan, sehingga didapatkan nilai-nilai yang digunakan untuk membuat kurva reaksi batuan breksi vulkanik (Tabel $1)$.

Tabel 1. Perhitungan Kurva Reaksi Batuan Breksi Vulkanik

\begin{tabular}{cccccc}
\hline \multicolumn{5}{c}{ Input } & \multicolumn{4}{c}{ Output } \\
\hline Jari-jari terowongan $(m)$ & $r o$ & 5,2 & Kuat tekan uniaksial $(M P a)$ & $\sigma_{c m}$ & 0,634 \\
\hline Sudut gesek dalam & $\varnothing$ & 25,21 & Ratio K & & 2,484 \\
\hline Kohesi c $(M P a)$ & $c$ & 0,201 & Tekanan kritis $(M p a)$ & $P c r$ & 0,113 \\
\hline Modulus Deformasi $(M P a)$ & $E$ & 11760,360 & Perpindahan maksimal $(m)$ & $u i_{\text {max }}$ & 0,0015 \\
\hline Nisbah Poisson's & $v$ & 0,24 & Zona plastik $(m)$ & $r p$ & 6,089 \\
\hline Tegangan in-situ $P o(M P a)$ & $P o$ & 0,513 & Zona plastik Diameter $(m)$ & 1,259 \\
\hline
\end{tabular}

Pada gambar 2, menunjukan hubungan penurunan $P i$ terhadap kenaikan perpindahan yang terjadi di terowongan. Perpindahan nol saat tekanan $P i$ sama dengan tegangan insitu $(P i=P o)$. Dari data tersebut diperoleh tekanan kritisnya sebesar $0,113 \mathrm{MPa}$ dengan perpindahan maksimalnya sebesar 1,464 mm. Jika tekanan peyangga $P i$ lebih besar dari tekanan kritis $P c r$, maka terowongan akan stabil dan perilaku massa batuan adalah elastis. Sebaliknya apabila tekanan penyangga $P i$ lebih kecil dari tekanan kritis $P c r$ maka terowongan tidak stabil.

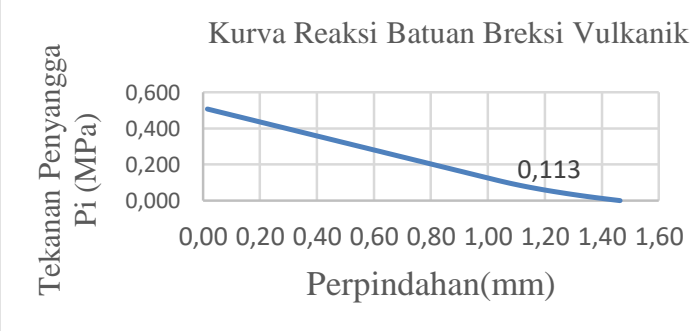 \\ Gambar 2. Kurva Reaksi Batuan \\ Breksi Menggunakan Metode \\ Convergen-Confinement Berdasarkan Solusi Analitik \\ Pada terowongan Notog, penggalian dilakukan setiap 1 meter tanpa diketahui berapa besar perpindahan awal yang terjadi pada dinding terowongan saat dilakukan pemasangan penyangga. Untuk mengetahui besar perpindahan ui terhadap jarak dari muka terowongan menggunakan kurva LDP.}

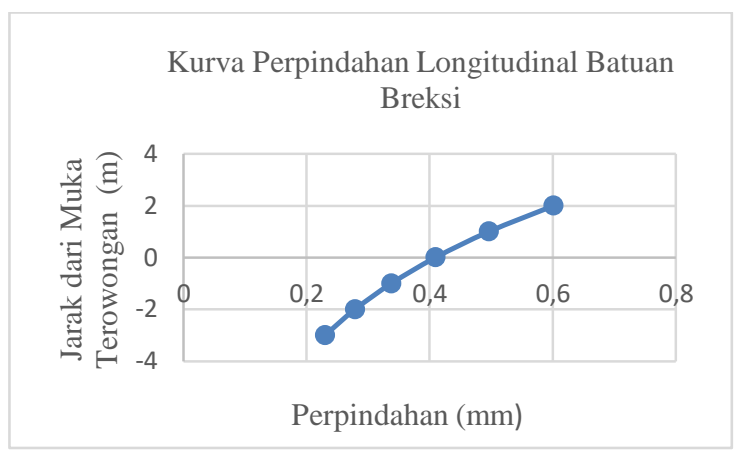

Gambar 3. Kurva Perpindahan Longitudinal Batuan Breksi Vulkanik Pada Saat Penggalian Dilakukan Setiap 1 Meter

Penyangga yang digunakan dalam proyek ini berupa penggunaan shotcrete, H-beam $125 \times 125, \mathrm{H}$ beam $150 \times 150$, rockbolt dan wiremesh yang pemasangannya 
dapat disesuaikan dengan kondisi dan desain dari pemodelan phase2. Sehingga didapatkan kurva karakteristik penyangga seperti pada gambar 4.

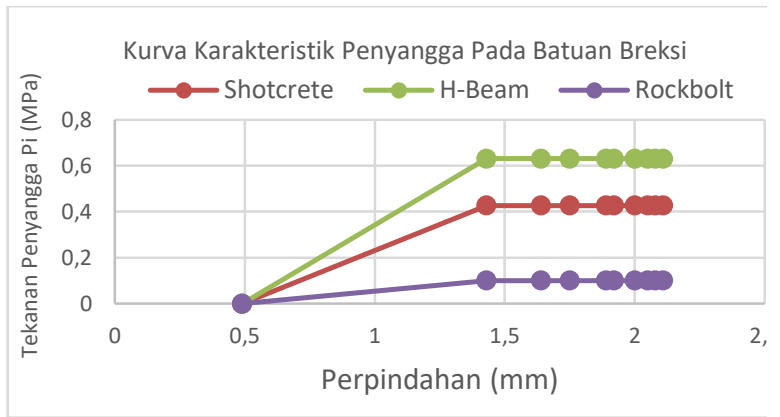

Gambar 4. Kurva Karakteristik Penyangga Pada Claystone

\section{b. Claystone}

Pengolahan data untuk membuat kurva interaksi batuan penyangga Claystone sama dengan batuan Breksi Vulkanik yang ada di inlet. Hanya saja kedalaman pada terowongan ini berada di kedalaman 22 meter dari permukaan tanah, sehingga tegangan in-situnya sebesar 0,59 MPa.

Tabel 2. Perhitungan Kurva Reaksi

\begin{tabular}{cccccc}
\multicolumn{7}{c}{ Batuan Claystone } \\
\hline Input \\
\hline Jari-jari terowongan $(m)$ & $r o$ & 5,2 & Kuat tekan uniaksial $(M P a)$ & $\sigma_{c m}$ & 0,430 \\
\hline Sudut gesek dalam & $\varnothing$ & 16,8 & Ratio K & & 1,813 \\
\hline Kohesi c $(M P a)$ & $c$ & 0,16 & Tekanan kritis $(M p a)$ & $P c r$ & 0,266 \\
\hline Modulus Deformasi $(M P a)$ & $E$ & 933,30 & Perpindahan maksimal $(m)$ & $u i_{m a x}$ & 0,007 \\
\hline Nisbah Poisson's & $v$ & 0,26 & Zona plastik $(m)$ & $r p$ & 8,579 \\
\hline Tegangan in-situ $P o(M P a)$ & $P o$ & 0,59 & Zona Plastik Diameter $(m)$ & 1,649 \\
\hline
\end{tabular}

Pada gambar 5 menunjukan hubungan penurunan $P i$ terhadap kenaikan perpindahan terowongan. Perpindahan nol saat tekanan $\mathrm{Pi}$ sama dengan tegangan in-situ $(P i=P o)$. Dari data tersebut diperoleh tekanan kritis terjadi pada perpindahan $2,48 \mathrm{~mm}$.

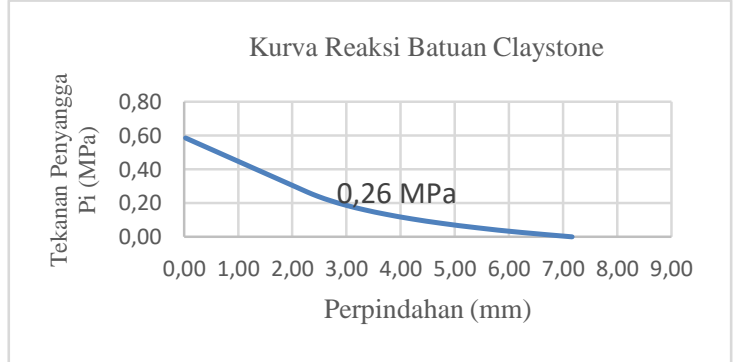

Gambar 5. Kurva Reaksi Batuan Claystone Menggunakan Metode ConvergenConfinement Berdasarkan Solusi Analitik

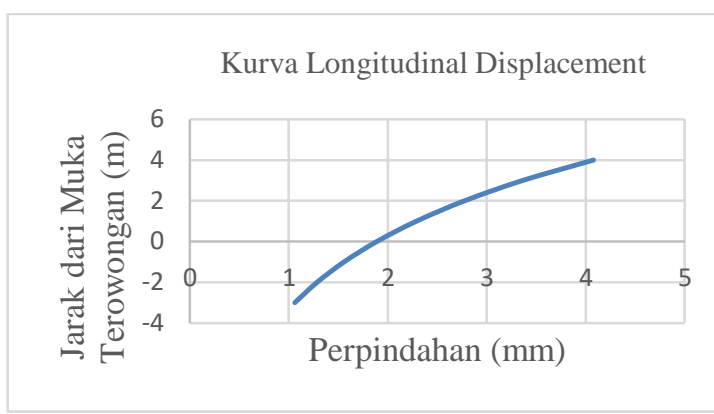

Gambar 6. Kurva Perpindahan

Longitudinal Batuan Claystone Pada Saat Penggalian Dilakukan Setiap 1 meter

Untuk batuan Claystone, penggalian dilakukan setiap 1 meter tanpa diketahui berapa besar perpindahan awal yang terjadi pada dinding terowongan saat dilakukan pemasangan penyangga. Untuk mengetahui besar perpindahan $u i$ terhadap jarak dari muka terowongan menggunakan kurva LDP. Berdasarkan hasil kurva karakteristik penyangga (gambar 7) dapat diketahui besar perpindahan pada saat dilakukan penggalian 1 meter adalah 2,2 $\mathrm{mm}$.

Penyangga yang digunakan dalam proyek ini berupa penggunaan shotcrete, H-beam $125 \times 125, \mathrm{H}$ beam $150 x 150$, rockbolt dan wiremesh yang pemasangannya dapat disesuaikain dengan kondisi dan desain dari pemodelan phase2. 


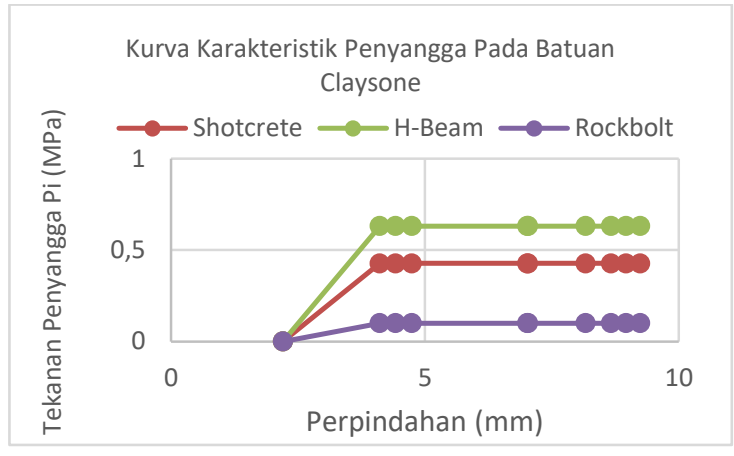

Gambar 7. Kurva Karakteristik Penyangga Pada Batuan Claystone

2. Kurva Interaksi Batuan-Penyangga Berdasarkan Solusi Numerik

Pemodelan numerik dilakukan dengan menggunakan Program Phase2, yang memakai metode elemen hingga (finite element method). Pemodelan ini dilakukan untuk mendapatkan perpindahan vertikal dan horizontal yang terjadi di sekeliling lubang bukaan, terutama pada dinding kanankiri dan atap terowongan.

\section{a. Breksi Vulkanik}

Titik STA $358+185$ berada pada kedalaman 18 meter dari permukaan tanah. Terowongan pada titik ini akan menembus batuan Breksi Vulkanik, seperti gambar 8 di bawah ini.

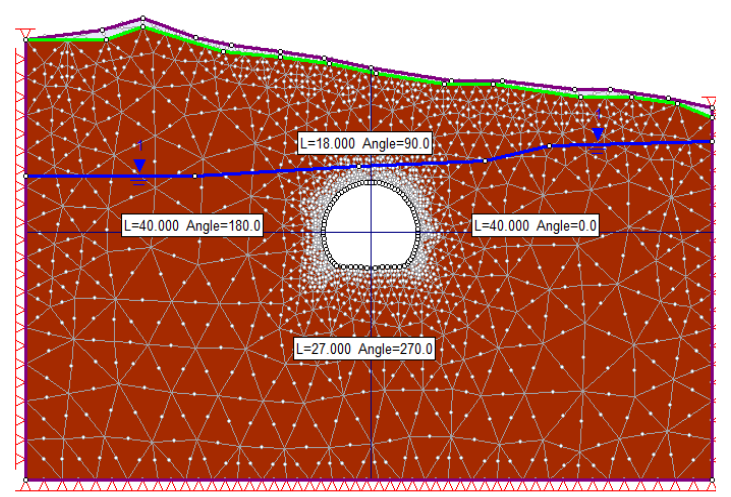

Gambar 8. Penampang STA 359+185

Dari hasil pemodelan Phase2, dibuat 10 kondisi Stage untuk mengetahui penurunan tekanan penyangga $P i$. Pada Stage pertama besaran dan arah beban akan sama dan berlawanan dengan tegangan in-situ, sehingga membentuk keseimbangan antara tekanan yang ada di batuan dan tekanan yang ada di dalam terowongan. Karena tekanannya sama dan berlawanan dengan tekanan, tidak ada perpindahan yang terjadi (atap, dan dinding kirikanan).

Namun, pada Stage kedua dan sesudahnya, dilakukan perhitungan beban dan secara bertahap tekanan akan berkurang. Akibatnya, perpindahan terowongan akan meningkat saat tekanan diturunkan menjadi nol. Faktor Stage sama dengan 1 berarti besarnya akan sama dengan tegangan in-situ yang terjadi di terowongan sementara faktor Stage sama dengan 0 berarti tidak ada beban yang akan diterapkan pada Stage itu.

Tabel 3. Penurunan Pi terhadap 3 Titik Pengamatan di STA 359+185
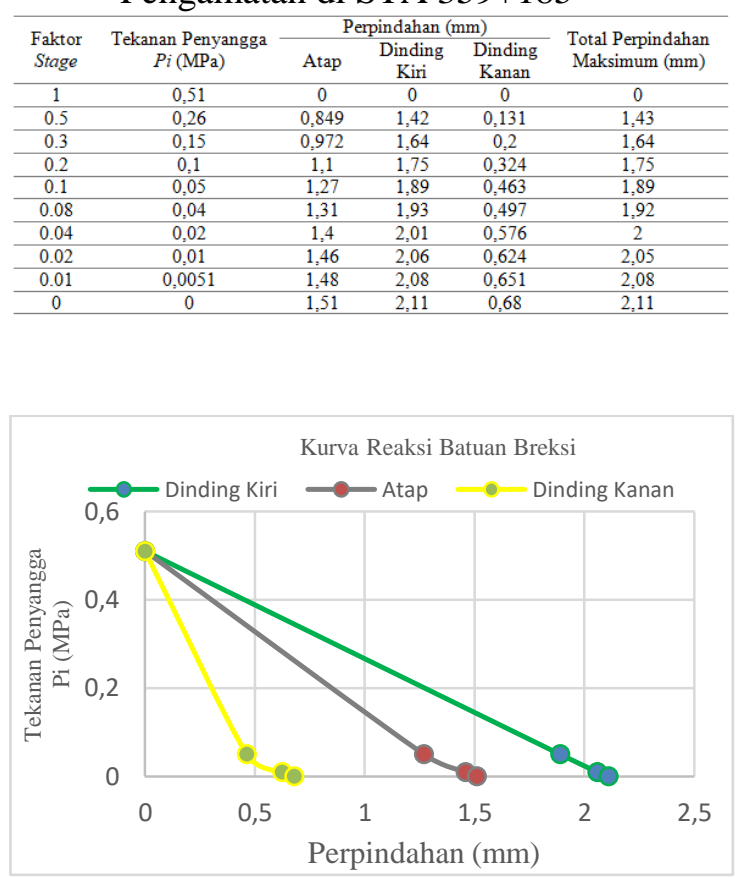

Gambar 9. Kurva Reaksi Batuan Breksi Vulkanik Berdasarkan Solusi Numerik 


\section{b. Claystone}

Titik STA 359+549 berada pada kedalaman 22 meter dari permukaan tanah. Terowongan pada titik ini akan menembus batuan Claystone, seperti yang ditunjukan pada gambar 10 di bawah ini. Kondisi batas yang diberikan pada model numerik di 359+549 yaitu Restrain (X,Y) atau tidak ada perpindahan yang terjadi pada sumbu $\mathrm{X}$ dan $\mathrm{Y}$ di batas kanan, kiri, dan bawah model (external boundary), yang disimbolkan dengan bentuk segitiga, sedangkan untuk batas atas tidak diberi kondisi batas karena mengikuti topografi yang ada. Kondisi pembebanan yang digunakan adalah kondisi pembebanan tipe gravitasi yaitu kondisi tegangan diatur agar bervariasi terhadap kedalaman. Penentuan kedalaman ditentukan menggunakan bentuk topografi (actual ground surface).

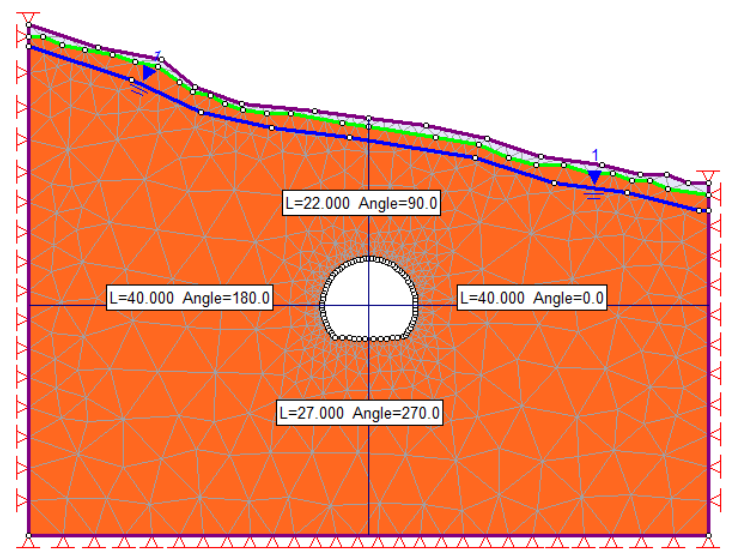

Gambar 10. Penampang STA 359+549

Sama halnya dengan batuan Breksi Vulkanik, pada batuan Claystone juga dibuat 10 kondisi Stage (Tabel 4) yang mempresentasikan penurunan $P i$. Hanya saja tekanan penyangga $P i$ berbeda dengan batuan Breksi Vulkanik.
Tabel 4. Penurunan Pi terhadap 3 Titik Pengamatan di STA $359+549$

\begin{tabular}{|c|c|c|c|c|c|}
\hline \multirow{2}{*}{$\begin{array}{c}\text { Faktor } \\
\text { Stage }\end{array}$} & \multirow{2}{*}{$\begin{array}{c}\text { Tekanan } \\
\text { Penyangga Pi } \\
(\mathrm{MPa})\end{array}$} & \multicolumn{3}{|c|}{ Perpindahan $(\mathrm{mm})$} & \multirow{2}{*}{$\begin{array}{c}\text { Total } \\
\text { Perpindahan } \\
\text { Maksimum (mm) }\end{array}$} \\
\hline & & Atap & $\begin{array}{c}\text { Dinding } \\
\text { Kiri }\end{array}$ & $\begin{array}{c}\text { Dinding } \\
\text { Kanan }\end{array}$ & \\
\hline 1 & 0,59 & 0 & 0 & 0 & 0 \\
\hline 0.6 & 0,35 & 3,24 & 4,1 & 1,03 & 4,11 \\
\hline 0.5 & 0,29 & 3,35 & 4,42 & 1,13 & 4,42 \\
\hline 0.4 & 0,24 & 3,46 & 4,75 & 1,13 & 4,74 \\
\hline 0.1 & 0,06 & 4,63 & 7,02 & 1,27 & 7,02 \\
\hline 0.08 & 0,05 & 4,87 & 7,33 & 1,35 & 7,32 \\
\hline 0.04 & 0,02 & 5,5 & 8,17 & 2,09 & 8,17 \\
\hline 0.02 & 0,01 & 5,88 & 8,68 & 2,51 & 8,67 \\
\hline 0.01 & 0,0059 & 6,09 & 8,96 & 2,75 & 8,96 \\
\hline 0 & 0 & 6,31 & 9,24 & 3,01 & 9,24 \\
\hline
\end{tabular}

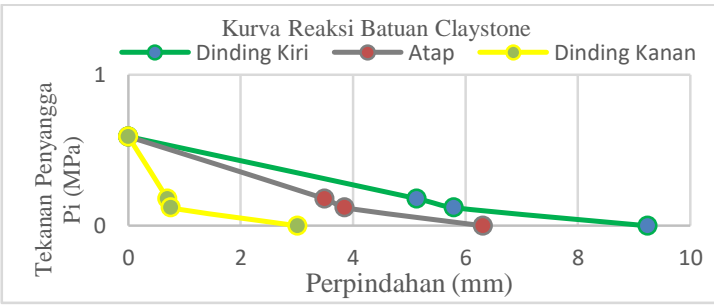

Gambar 11. Kurva Reaksi Batuan Claystone Berdasarkan Solusi Numerik

\section{HASIL DAN PEMBAHASAN}

1. Perbandingan Kurva Reaksi Batuan Berdasarkan Solusi Numerikdan Solusi Analitik

Berdasarkan hasil perhitungan dari solusi numerik, besar perpindahan yang terjadi di terowongan (atap, dinding kiri dan dinding kanan) mendekati hasil perhitungan dari kurva interaksi batuanpenyangga, hal ini disebabkan karena adanya perbedaan bentuk geometri terowongan. Perhitungan secara analitik kurva interaksi batuan-penyangga hanya dapat digunakan untuk terowongan yang berbentuk lingkaran, sedangkan untuk terowongan Notog mempunyai geometri terowongan berbentuk tapak kuda.

a. Batuan Breksi Vulkanik

Perbandingan hasil perhitungan kurva interaksi batuan-penyangga dengan metode numerik untuk batuan Breksi Vulkanik dapat dilihat pada gambar 12. Berdasarkan hasil analisis numerik dengan menggunakan rasio tegangan insitu $\mathrm{K}=1$ dan kekuatan material dari 
batuan didapatkan besar perpindahan yang terjadi pada dinding kiri lebih besar dari pada dinding kanan dan atap.

Tabel 5. Perbandingan Perhitungan Kurva Reaksi Batuan Breksi Vulkanik Berdasarkan Solusi Numerik dan Solusi Analitik

\begin{tabular}{|c|c|c|c|c|}
\hline \multirow{2}{*}{$\begin{array}{c}\text { Tekanan } \\
\text { Penyangga } \\
P i(\mathrm{MPa})\end{array}$} & \multicolumn{3}{|c|}{ Perpindahan Solusi Numerik (mm) } & \multirow{2}{*}{$\begin{array}{c}\text { Perpindahan } \\
\text { Solusi } \\
\text { Analitk }(\mathrm{mm})\end{array}$} \\
\hline & Atap & $\begin{array}{c}\text { Dinding } \\
\text { Kiri }\end{array}$ & $\begin{array}{c}\text { Dinding } \\
\text { Kanan }\end{array}$ & \\
\hline 0,51 & 0 & 0 & 0 & 0 \\
\hline 0,26 & 0,849 & 1,42 & 0,131 & 0,655 \\
\hline 0,15 & 0,972 & 1,64 & 0,2 & 0,916 \\
\hline 0,1 & 1,1 & 1,75 & 0,324 & 1,063 \\
\hline 0,05 & 1,27 & 1,89 & 0,463 & 1,208 \\
\hline 0,04 & 1,31 & 1,93 & 0,497 & 1,252 \\
\hline 0,02 & 1,4 & 2,01 & 0,576 & 1,350 \\
\hline 0,01 & 1,46 & 2,06 & 0,624 & 1,405 \\
\hline 0,0051 & 1,48 & 2,08 & 0,651 & 1,431 \\
\hline 0 & 1,51 & 2,11 & 0,68 & 1,464 \\
\hline
\end{tabular}

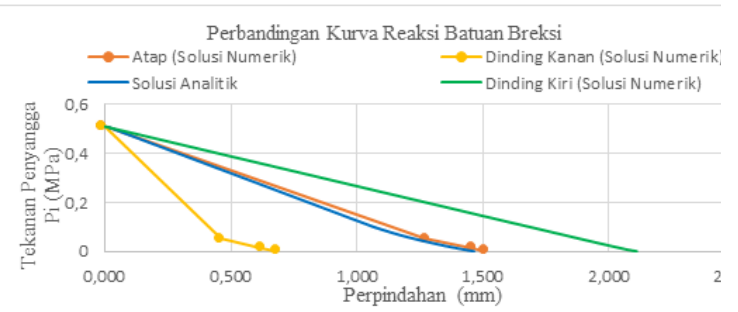

Gambar 12. Perbandingan Kurva Reaksi Batuan Breksi Vulkanik Menggunakan Metode Convergen-Confinement Berdasarkan Solusi Numerik dan Solusi Analitik

\section{b. Claystone}

Perbandingan hasil perhitungan kurva interaksi batuan-penyangga dengan metode numerik untuk batuan Claystone dapat dilihat pada gambar 13. Sama halnya dengan batuan Breksi Vulkanik, hasil analisis numerik dengan menggunakan rasio tegangan insitu $\mathrm{K}=1$ untuk Claystone dan kekuatan material dari batuan didapatkan besar perpindahan yang terjadi pada dinding kiri lebih besar dari pada dinding kanan dan atap.
Tabel 6. Perbandingan Perhitungan

Kurva Reaksi Batuan Claystone

Berdasarkan Solusi Numerik dan Solusi Analitik

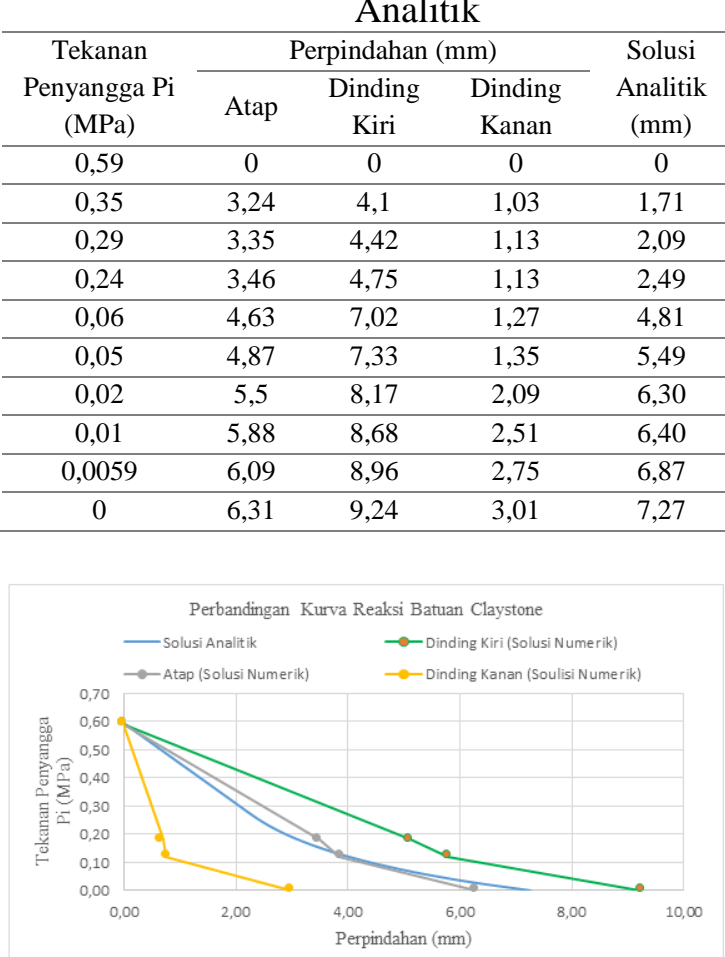

Gambar 13. Perbandingan Kurva Reaksi

Batuan Claystone Menggunakan Metode Convergen-Confinement Berdasarkan Solusi Numerik dan Solusi Analitik

Perhitungan kurva interaksi batuanpenyangga secara analitik tidak dapat dilakukan, dikarenakan pada persamaan analitik yang digunakan untuk menghitung perpindahan di batas galian terowongan dikembangkan berdasarkan asumsi ideal, yaitu kondisi batuan homogen, elastik dan isotrop, terowongan berpenampang lingkaran, dan kondisi tegangan hidrostatik, sedangkan untuk metode numerik geometri terowongan berbentuk tapak kuda (Budi Sulistianto, Tri Karian, 2009).

2. Perbandingan Kurva Interaksi Batuan Penyangga Berdasarkan Solusi Numerik dengan Hasil Pemantauan

Data perpindahan terowongan diperoleh dari hasil perhitungan 
lapangan menggunakan alat total station. Data tersebut menunjukkan perpindahan yang terjadi di setiap titik per harinya. Besar dan arah pergerakan yang diamati mengalami pergerakan secara horizontal dan vertikal.

\section{a. Breksi Vulkanik}

Perbandingan perhitungan kurva interaksi batuan-penyangga dengan hasil pemantauan yang dilakukan di lokasi penelitian dengan 3 titik berbeda yaitu dinding kiri-kanan dan atap terowongan (gambar 14). Kurva ini mempresentasikan penurunan tekanan penyangga $P i$ dan peningkatan perpindahan $u i$ terhadap waktu (hari). Tekanan peyangga $P i$ diubah dalam bentuk persen untuk lebih memudahkan dalam membandingkan perhitungan penurunan tekanan penyangga $\mathrm{Pi}$ terhadap waktu.

Berdasarkan hasil analisis kurva longitudinal displacement profile, perpindahan awal yang terjadi pada saat pemasangan penyangga sebesar $0,49 \quad \mathrm{~mm}$. Dimana sistem penyanggaan yang digunakan di lokasi penelitian adalah gabungan dari shortcrete, rockbolt, wiremesh dan H-Beam. Titik kesetimbangan (Equilibrium) akan tercapai, jika kurva interaksi batuan-penyangga memotong kurva reaksi batuan Breksi Vulkanik sebelum salah satu dari kurva mengalami perpindahan yang lebih besar. Pada gambar tersebut, memperlihatkan bahwa pada titik kesetimbangan (equilibrium) yang terjadi pada penyangga shotcrete yaitu $0,9 \mathrm{~mm}$ dan untuk penyangga $\mathrm{H}$-Beam yaitu 0,8 mm. Sedangkan untuk kurva karakteristik penyangga Rockbolt, tidak mencapai titik kesetimbangan (nilai psm lebih kecil dari titik kesetimbangan) sehingga sistem penyangga tidak akan efektif, karena tidak mencapai kondisi kesetimbangan tersebut.

\section{b. Claystone}

Perbandingan perhitungan kurva interaksi batuan-penyangga dengan hasil pemantauan yang dilakukan di lokasi penelitian dengan 3 titik berbeda yaitu dinding kiri-kanan dan atap terowongan dapat dilihat pada gambar 15. Kurva ini mempresentasikan penurunan tekanan penyangga $P i$ dan peningkatan perpindahan $u i$ terhadap waktu (hari). Tekanan peyangga $P i$ diubah dalam bentuk persen untuk lebih memudahkan dalam membandingkan perhitungan penurunan tekanan penyangga $\mathrm{Pi}$ terhadap waktu.

Berdasarkan hasil analisis kurva longitudinal displacement profile, perpindahan awal yang terjadi pada saat pemasangan penyangga sebesar $2,4 \mathrm{~mm}$. Dimana sistem penyanggaan yang digunakan di lokasi penelitian adalah gabungan dari shortcrete, rockbolt, wiremesh dan H-Beam. Pada gambar tersebut memperlihatkan bahwa pada titik kesetimbangan (equilibrium) yang terjadi pada penyangga shotcrete yaitu $3,2 \mathrm{~mm}$ dan untuk penyangga $H$-Beam yaitu 3,1 mm. Sedangkan untuk kurva karakteristik penyangga Rockbolt, tidak mencapai titik kesetimbangan (nilai psm lebih kecil dari titik kesetimbangan) sehingga sistem penyangga tidak akan efektif, karena tidak mencapai kondisi kesetimbangan tersebut.

Perbandingan antara hasil pengamatan massa batuan setelah disangga dengan hasil perhitungan dari kurva interaksi batuan-penyangga terjadi perbedaan. Perpindahan yang terjadi dari hasil pemantauan dilapangan sekitar 5,5 mm untuk dinding kiri-kanan dan atap sedangkan untuk hasil perhitungan perpindahan yang terjadi pada pada massa 
batuan setelah disangga adalah $3,1 \mathrm{~mm}$ dan 3,2 mm (titik equilibrium).

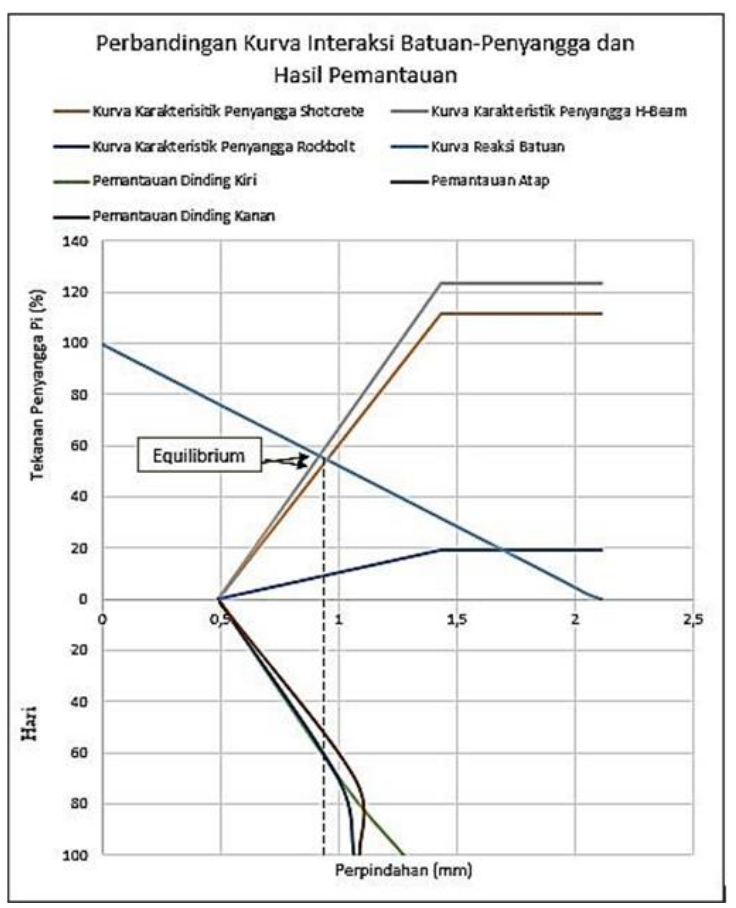

Gambar 14. Perbandingan Kurva Interaksi Batuan-Penyangga (Solusi Numerik) dengan Hasil Monitoring Pada Batuan Breksi Vulkanik

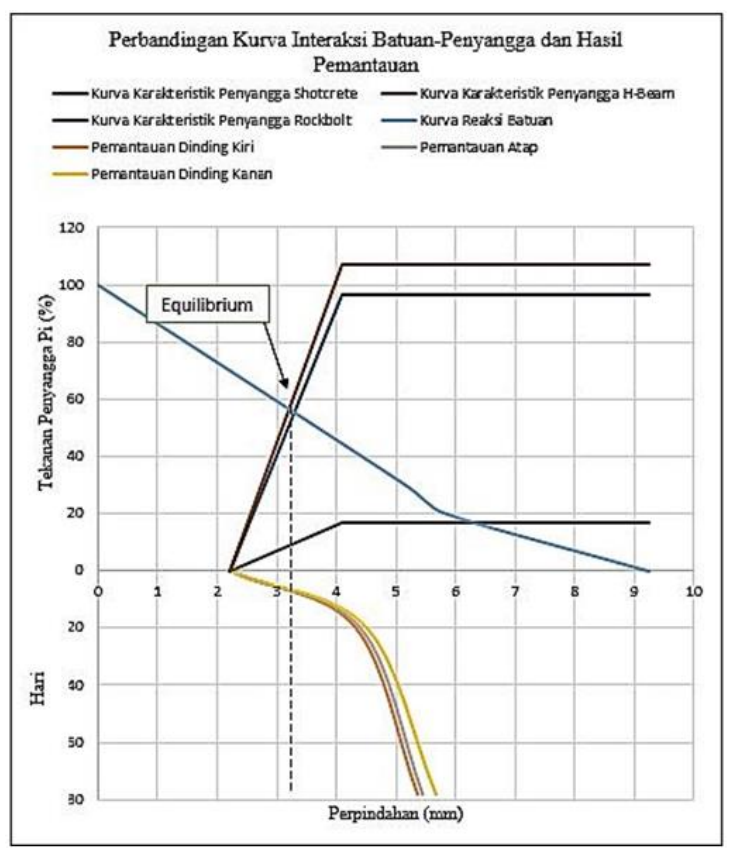

Gambar 15. Perbandingan Kurva Interaksi Batuan-Penyangga (Solusi Numerik) dengan Hasil Pemantauan Pada Batuan Claystone

\section{KESIMPULAN}

Dalam penelitian ini dapat diambil kesimpulan bahwa:

1. Perhitungan kurva interaksi batuanpenyangga secara analitik tidak dapat dilakukan untuk terowongan dangkal. Dikarenakan pada persamaan analitik yang digunakan untuk menghitung perpindahan di batas galian terowongan dikembangkan berdasarkan asumsi ideal, yaitu kondisi batuan homogen, elastik dan isotrop, terowongan berpenampang lingkaran, dan kondisi tegangan hidrostatik.

2. Kurva interaksi batuan-penyangga dapat ditentukan dengan perhitungan menggunakan metode numerik (elemen hingga) dalam desain penyangga untuk terowongan tidak berbentuk lingkaran.

3. Perhitungan kurva interaksi batuanpenyangga secara numerik menunjukan kemiripan dengan hasil pemantauan yang terjadi dilapangan. Ini terlihat dari besar perpindahan yang terjadi di terowongan, dimana titik pengamatan dinding kiri-kanan dan atap mendekati hasil perhitungan dari kurva interaksi batuan penyangga dan pemodelan numerik

4. Hasil analisis Longitudinal Deformation Profile (LDP) untuk batuan Breksi Vulkanik, besar perpindahan pada saat dilakukan penggalian 1 meter dari penyangga terakhir adalah $0,49 \mathrm{~mm}$. Untuk batuan Claystone, besar perpindahan pada saat dilakukan penggalian 1 meter dari penyangga terakhir adalah $2,4 \mathrm{~mm}$

5. Perpindahan yang terjadi pada batuan Breksi Vulkanik dari hasil pemantauan dilapangan rata-rata sekitar $1,15 \mathrm{~mm}$ untuk dinding kiri-kanan dan atap sebesar $1 \mathrm{~mm}$, sedangkan untuk hasil perhitungan perpindahan yang terjadi pada pada massa batuan setelah disangga adalah $1,1 \mathrm{~mm}$ dan $0,9 \mathrm{~mm}$ (titik equilibrium).

6. Perpindahan yang terjadi pada batuan Claystone dari hasil pemantauan dilapangan rata-rata sekitar 4,1 $\mathrm{mm}$ 
untuk dinding kiri-kanan dan atap sebesar 3,1 mm, sedangkan untuk hasil perhitungan perpindahan yang terjadi pada pada massa batuan setelah disangga adalah $3,1 \mathrm{~mm}$ dan $3,6 \mathrm{~mm}$ (titik equilibrium).

\section{DAFTAR PUSTAKA}

Bieniawski, Z.T.(1984). Rock mechanics design in mining and tunneling. AA Balkema, Rotterdam

Brady, B.H.G. and Brown, E.T.(1985). Rock mechanics for underground mining. Allen and Unwin, London

Carranza-Tores, C., Fairhurst, C., 2000, Application of the ConvergenConfinement Method of Tunnel Design to Rock Masses that Satisfy the Hoek-Brown Failure Criterion, Tunn. Underground Sp. Tech, 15(2), 187-213

Hoek, E., and Brown, E.T. (1980). Underground excavations in rock. Instn Min. Metall., London

Hoek, E., Kaiser, P.K., Bwaden, W.F. (1995),Support of Underground Excavations in Hard Rock. A. A Balkema, Rotterdam.

Hoek, E. (1999). Support for very weak rock associated with faults and shear zones. Distinguished lecture for the opening of the Intl. Symp. on Rock Support and Reinforcement Practice in Mining, Kalgoorlie, Australia, 14-19 March.

Prassetyo S.H., Wattimena R.K., (2018). Integration of Ground Reaction Curve and Equilibrium Strain Approach in Design Tunnel Support System in Weak Rock Masses, The ISRM International Symposium for 2018
Rai, M.A., Kramadibrata, S., dan Watimena, R.K. 2011. Mekanika Batuan. Bandung:Institut Teknologi Bandung.

Sulistianto, B., Karian T., (2009). Perhitungan Kurva Reaksi Batuan Menggunakan Pendekatan Metode Numerik,. JTM

Vlachopoulos, N., Diederichs, M. S., 2009, Improved Longitudinal Displacement Profiles for Convergence Confinement Analysis of Deep Tunnel, Rock Mech. Rock Engi., 42(2), 131-146 